\title{
Coastal aquifer hydrodynamics and salinity in response to the tide: case study in Lisbon, Portugal
}

\author{
M. Mancuso, E. Carol, E. Kruse and F. Mendes Rodrigues
}

\begin{abstract}
The variability in dynamics and salinity of the coastal alluvial aquifer on which the city of Lisbon is located was evaluated. Such an evaluation was based on the analysis of level and groundwater electrical conductivity fluctuations depending on the tide in the Tagus River. The results obtained made it possible to recognize three sectors. First, a littoral sector where the variations in level and salinity are larger on the coast and decrease towards the innermost sections of the alluvial fan. Second, a sector close to the docks where there is greater dynamic and salinity variability than in the coastal sectors, as the excavations of the docks favour the tidal propagation towards the aquifer. And third, a sector located towards the apex of the alluvial fan associated with the dynamics of the stormwater channel. In this sector, the largest periodical water table fluctuations in the aquifer occur, since the freshwater that cannot drain towards the river enters the aquifer at high tide, causing a slight decrease in salinity content. On the basis of these results, conceptual models of hydrogeological behaviour were used to describe the spatial and temporal variations in the hydrodynamic and salinity characteristics of groundwater.
\end{abstract}

Key words | coastal aquifer, conceptual models, Lisbon, salinity variability, tidal hydrodynamics

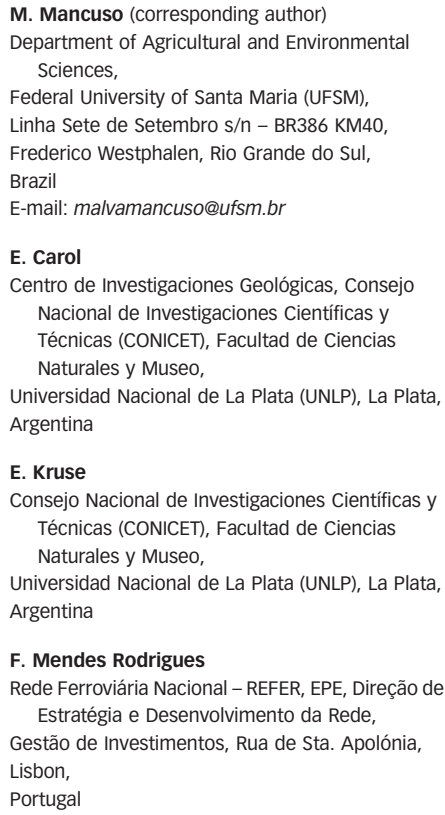

F. Mendes Rodrigues

Rede Ferroviária Nacional - REFER, EPE, Direção de Estratégia e Desenvolvimento da Rede, Gestão de Investimentos, Rua de Sta. Apolónia Lisbon, Portugal

\section{INTRODUCTION}

The complexity of the problems related to coasts has increased in the last few decades as a result of the impact of different human activities and uses. It is estimated that $80 \%$ of the world population lives less than $100 \mathrm{~km}$ from the coast and this tendency continues to increase. This implies that there are millions of people who demand space for housing, work and recreation, construction materials, food, drinking water, and so on. Therefore, the major challenge today is undoubtedly to develop specific technological, scientific, economic and legal resources to successfully deal with the needs that such transformations create.

Spatial and temporal variability in groundwater dynamics and salinity in coastal areas is a widely studied topic. The research carried out in different regions worldwide (e.g., Park et al. 2005; Ghabayen et al. 2006; Kim et al. 2006; Giambastiani et al. 2007; Rosenthal et al. 2007; Antonellini et al. 2009; Carol et al. 2009, 2012; SilvaFilho et al. 2009; Currell et al. 20I3; Jun et al. 20I3; Shapouri et al. 2015; Surinaidu 2015) shows highly dissimilar behaviours, which is evidence of the hydrological complexity of coastal aquifers.

The city of Lisbon, situated at the mouth of the Tagus River, is the capital and largest city of Portugal, concentrating $20 \%$ of the country's population, approximately 600,000 inhabitants, in an $85 \mathrm{~km}^{2}$ area (Alcoforado et al. 2009). The Lisbon Metropolitan Area is one of the fastest growing urban agglomerations in the European Union, and it is estimated that its population will grow to 4.5 million inhabitants by 2050 . As in any coastal city, the underlying 
aquifers show changes in dynamics and salinity, conditioned in this case by the tidal flow entering the Tagus River from the Atlantic Ocean.

The objective of this work is to assess the variability in dynamics and salinity of the coastal alluvial aquifer in Lisbon on the basis of the analysis of the variations in groundwater electrical conductivity (EC) and level depending on the tide in the Tagus River. Even though the water of the aquifer is not used for human consumption, the importance of recognizing such an influence mainly lies in that the dynamics and salinity of the groundwater condition the useful life of the structures and urbanizations that have been developed in the aquifer. In coastal aquifers, the influence of seawater causes premature deterioration of constructions (through alteration of the constitutive material of concrete, corrosion of metallic alloys, etc.), reducing their useful life (Gjørv \& Vennesland I979; Jinjie \& Wei 20II). A detailed understanding of the tidal influence on the aquifer will make it possible to better define the environmental conditions that construction materials are subjected to and to take precautions when developing construction projects. A knowledge of subsurface hydrodynamics may also be of help in urban planning, for instance allowing the demarcation of favourable areas for rainwater infiltration or less favourable areas for the construction of underground structures which, due to the obstruction of the flow, may contribute to the flooding of lower-lying areas.

\section{STUDY AREA}

The study area is in a coastal sector of the city of Lisbon, located in western Portugal. The climate is Mediterranean, influenced by the Gulf Stream, with an average temperature of $17^{\circ} \mathrm{C}$, maximum temperatures of over $27^{\circ} \mathrm{C}$ in July and August, and a minimum temperature of $11.3^{\circ} \mathrm{C}$ in January. Rainfall shows a mean annual value of $726 \mathrm{~mm}$, with December being the wettest month $(121.8 \mathrm{~mm})$ and July the driest $(6.1 \mathrm{~mm})$.

The estuary of the Tagus River is one of the largest on the European Atlantic coast with a length of $50 \mathrm{~km}$ and an area of $325 \mathrm{~km}^{2}$, about $40 \%$ of which is an intertidal area. The average depth is less than $10 \mathrm{~m}$ and the greatest depths $(\sim 40 \mathrm{~m})$ occur close to the mouth of the estuary. The mean river flow, which shows high seasonal and interannual variability, is $400 \mathrm{~m}^{3} \mathrm{~s}^{-1}$. Salinity ranges from $0 \% 0$ at $50 \mathrm{~km}$ upstream from the mouth to almost 37\% at the mouth of the estuary (França et al. 2005).

The city of Lisbon is built over alluvial sediments where an unconfined aquifer, whose saturated thickness is of up to $40 \mathrm{~m}$, occurs. This alluvial aquifer is limited at its base by the Lisbon Volcanic Complex (basalts) and partially to the north by compact calcareous rocks (Almeida I986) (Figure 1) (full colour versions of all figures are available in the online version of this paper, doi: $\mathrm{xx} . \mathrm{xxxx} / \mathrm{xx} . \mathrm{xxxx} \cdot \mathrm{xxx}$ ). It is mainly constituted by medium- to fine-grained sand with intercalations of silty-sandy levels. Groundwater in the coastal

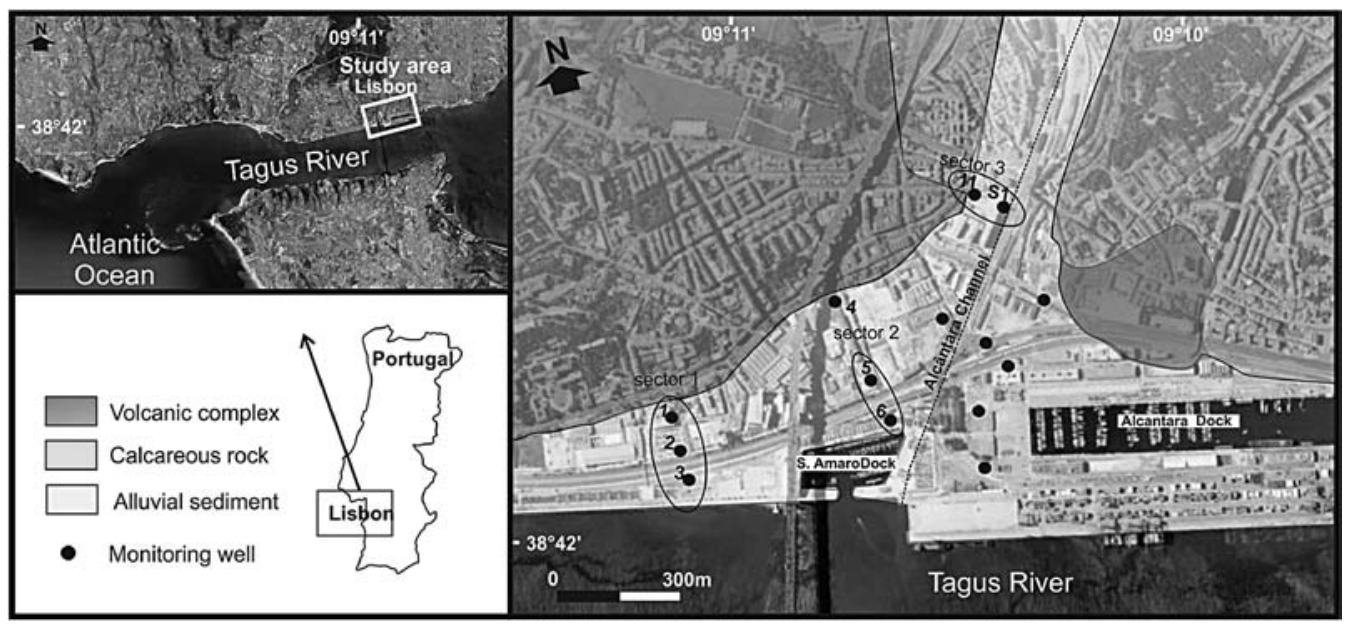

Figure 1 | Location of the study area and sampling points. (Full colour version available online.) 
sector is related to the Tagus River which is under the tidal influence of the Atlantic Ocean and, in the central sector, to the Alcântara Channel, which is a channelized surface watercourse with a permeable base that flows across the sector from north to south and into the Tagus River.

\section{METHODOLOGY}

\section{Study design}

The hydrogeological characteristics of the unconfined aquifer were studied on the basis of boreholes, taking samples and measuring the groundwater level and EC. The boreholes were drilled by percussion drilling until the basement was reached, so as to cover the total thickness of the aquifer. The wells are 4 inches in diameter and each of them has a well-selected siliceous gravel pre-filter and a continuous slot filter in PVC tubing. During the well drilling process, the lithological description of the sediments was carried out.

In order to analyze the variations in groundwater level and salinity depending on the tide of the Tagus River, continuous water level and EC measurement sensors were installed (records every $10 \mathrm{~min}$ ) in the exploration wells, and level measurements were carried out in the river. In the wells, EC measurements were also undertaken in groundwater at different levels of the water column on the basis of continuous record sensors located in the basal, middle and superficial parts of the aquifer.

\section{Data analysis}

Between April and October 2009, continuous level, temperature and EC measurements were carried out by means of sensors that were installed in rotation in the different wells of the monitoring network. In order to analyze a similar hydrological situation, the measurement period comprising April and May 2009 was chosen. The selection of this period was based on the fact that it concentrated most of the data from the sensors located at different depths, which made it possible to analyze the EC and temperature variations throughout the thickness of the aquifer. The groundwater level data, as well as those of the Tagus
River, were set at a similar zero level for reference, expressing the values in metres below or above such level.

The detailed study of the spatial variability in dynamics and salinity of the aquifer was carried out on the basis of measurements obtained from Wells 1, 2, 3, 4, 5, 6, 11 and S1 (Figure 1). The groundwater level, EC and temperature data were plotted in relation to time and compared with the level data obtained for the Tagus River in order to determine the response of these parameters to the tidal oscillations of the river.

So as to determine the location of the salt wedge and estimate quantitatively the area of tidal influence, the data obtained were incorporated into a geographic information system. Furthermore, the level and EC records of the wells at different levels were used to construct hydrogeological cross-sections in order to identify the dynamics of the groundwater flow in relation to the tide and the location of the salt wedge within the study area.

\section{RESULTS}

\section{Tidal influence on groundwater level, EC and temperature}

In the period analyzed, the maximum tidal oscillations range between -1.74 and $1.61 \mathrm{~m}$, showing ranges close to $1 \mathrm{~m}$ at quadrature and to $3 \mathrm{~m}$ at syzygy. At low tide, the groundwater levels in all of the studied wells provide evidence that the regional groundwater flow direction is from the apex of the alluvial cone towards the Tagus River. In most wells, groundwater level oscillations associated with the tidal flows were recorded, as well as the presence of salinity stratification, demarcating three sectors with different behaviours (Figure 1).

\section{Sector 1}

Sector 1 (Figure 1) is located at the southwest end of the alluvial cone, in a zone where there are two large underground parking garages. The aquifer has a thickness of $13 \mathrm{~m}$ on the coast, becoming wedge-shaped towards the northwest until it disappears where the basaltic basement 
crops out. The alluvial sediments are composed of sand with intercalations of silty to clayey lenses.

The variations in level and EC of groundwater in a transect perpendicular to the coastline, which includes Wells 1,2 and 3 (Figure 1), make it possible to visualize the tidal influence on the hydrodynamic behaviour and salinity of the aquifer. The groundwater level and EC records in the well farthest from the coastline (Well 1, installed $200 \mathrm{~m}$ from the Tagus River) show that there are no significant variations in such parameters depending on the tide (Figure 2). Throughout most of the period analyzed, the values of the water table remained close to $0.63 \mathrm{~m}$ and the $\mathrm{EC}$ of the groundwater shows average values of approximately $1.50 \mathrm{mS} / \mathrm{cm}$, with a slight increase in EC at some high spring tides.

In Well 2, located $145 \mathrm{~m}$ from the river, slight oscillations in the water table and EC associated with the tidal flows in the river were recorded (Figure 2). At low tide, the water table has an average height of $0.57 \mathrm{~m}$, with increases at the onset of the high tide. At high neap tides, the water level does not vary or shows variations below $0.05 \mathrm{~m}$, whereas at high spring tides an average increase of $0.10 \mathrm{~m}$ with respect to its position at low tide was recorded. In turn, the average EC of the groundwater is $1.2 \mathrm{mS} / \mathrm{cm}$, with maximum variations of $0.4 \mathrm{mS} / \mathrm{cm}$ between the low neap tide and the high spring tide.

The groundwater EC in Well 2 recorded at different depths (Figure 3) shows evidence of salinity stratification, with average values of $11 \mathrm{mS} / \mathrm{cm}$ at the base and $1.5 \mathrm{mS} / \mathrm{cm}$ on the surface. At high tide, the EC of the groundwater tends to increase in the most superficial sections of the aquifer (records from depths of -0.5 and $-3.7 \mathrm{~m}$ ), whereas at depth it remains constant (records from a depth of $-6.8 \mathrm{~m}$ ). It should be noted that, while the maximum peaks of the water table occur before the high tide in the river, the highest values of EC in groundwater appear with a delay with respect to the high tide in the river.

In the area closest to the coastline (Well 3, located $70 \mathrm{~m}$ from the river), a similar behaviour to that of Well 2 can be observed, although the former has larger amplitudes in the fluctuation of the water table and higher salinity content (Figure 2). At low tide, the average water table is $0.22 \mathrm{~m}$ and it increases at the onset of the high tide. At high neap tides, increases in the water table of $0.22 \mathrm{~m}$ with respect to its position at low tide are recorded, whereas at syzygy they reach $0.83 \mathrm{~m}$. The average $\mathrm{EC}$ of groundwater is $9.30 \mathrm{mS} / \mathrm{cm}$, with increases at high tide that are more noticeable at high spring tides.

The EC of groundwater measured at different levels in the water column (Figure 3) shows salinity stratification with average values of $18.6 \mathrm{mS} / \mathrm{cm}$ at the bottom of the well and $9.2 \mathrm{mS} / \mathrm{cm}$ on the surface. At high tide, the EC of groundwater tends to increase in the shallower areas (records from depths of -1.2 and -4.4 m.a.s.l.), while at depth they remain constant (records from depths of -6.8 and -7.5 m.a.s.l.).

\section{Sector 2}

Sector 2 (Figure 1) comprises a sector near the docks at the Santo Amaro port, where the surface water level fluctuates as the Tagus River fluctuates with the tide. The alluvial aquifer has a thickness of approximately $21 \mathrm{~m}$, with sediments composed of sand, which become sandy-silty to clayey facies towards the base.

Level and EC data of groundwater in Wells 5 and 6 (Figure 4) were analyzed. Well 5 is located $200 \mathrm{~m}$ from the docks and $370 \mathrm{~m}$ from the riverbank, and Well 6 is located $70 \mathrm{~m}$ from the docks and $240 \mathrm{~m}$ from the riverbank.

The water table levels in Well 5 show that at low tide the average level is $0.22 \mathrm{~m}$ and that it rises periodically at high tide (Figure 4). During high spring tides, the increases reach $0.36 \mathrm{~m}$ with respect to their low-tide position, whereas during neap tides the increases are $0.10 \mathrm{~m}$, with the highest groundwater level peaks occurring after the low tide peaks in the river.

Groundwater EC also shows the tidal influence, with an average value at low tide of $2.60 \mathrm{mS} / \mathrm{cm}$ (at $-13.4 \mathrm{~m}$ ) and recorded increases of 0.1 and $0.2 \mathrm{mS} / \mathrm{cm}$ at high tide (Figure 4). The groundwater EC records at different levels (Figure 5) show salinity stratification, with average values of $5.5 \mathrm{mS} / \mathrm{cm}$ at $-16 \mathrm{~m}, 2.9 \mathrm{mS} / \mathrm{cm}$ at $-8 \mathrm{~m}$ and $2.5 \mathrm{mS} / \mathrm{cm}$ at $-1.0 \mathrm{~m}$. At the base of the aquifer, the EC of groundwater does not vary with the tide, whereas in the middle and shallow sections of the water column, a slight increase is recorded at high tide (Figure 5).

At Well 6, the average level at low tide is $0.17 \mathrm{~m}$, which increases at the onset of the high tide. At high neap tides, the water table rises $0.18 \mathrm{~m}$ with respect to its position at low 

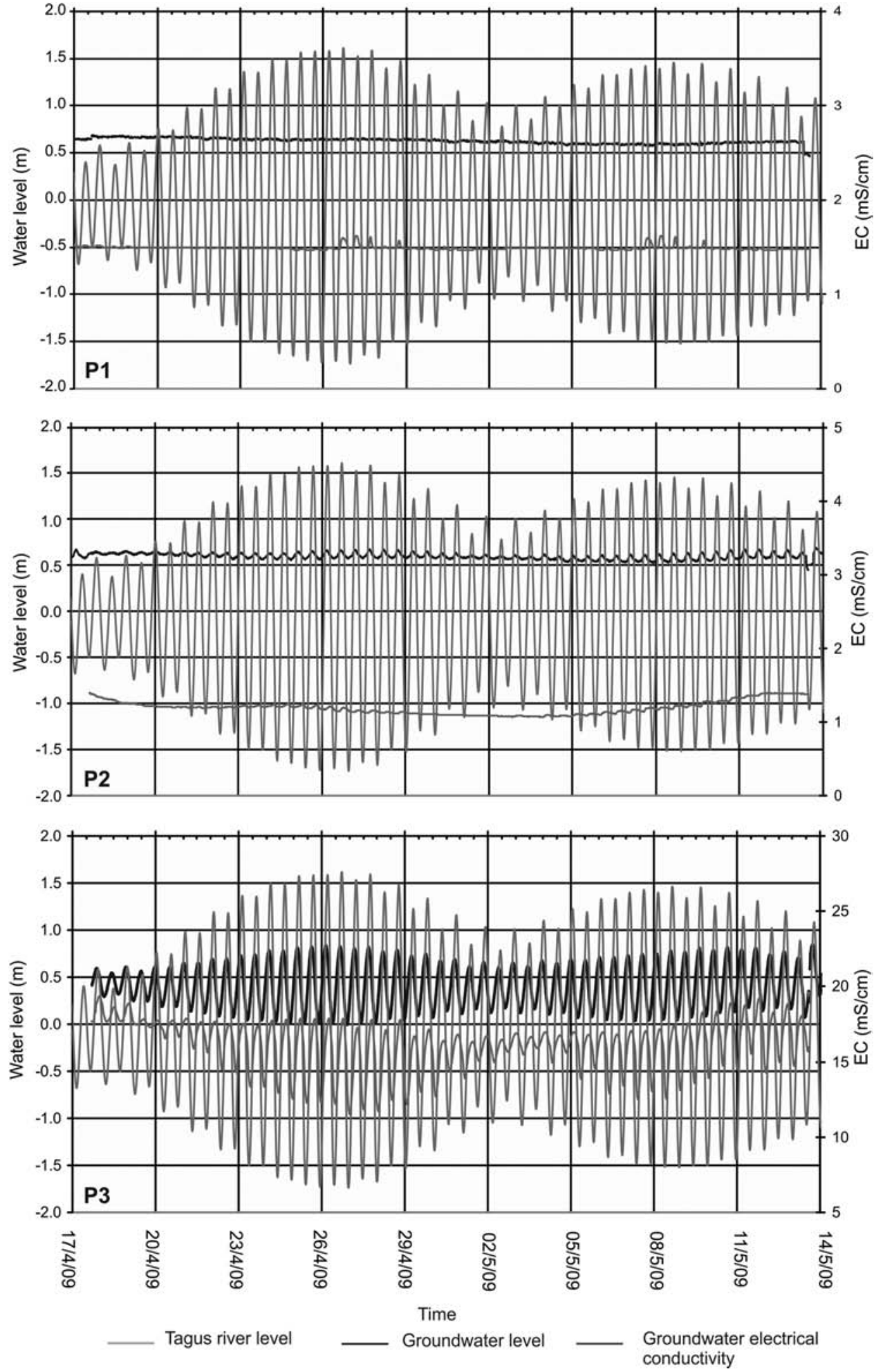

Figure 2 | Diagram of groundwater level and EC variations in Wells 1, 2 and 3, and of the tide in the Tagus River depending on the time. (Full colour version available online.) 


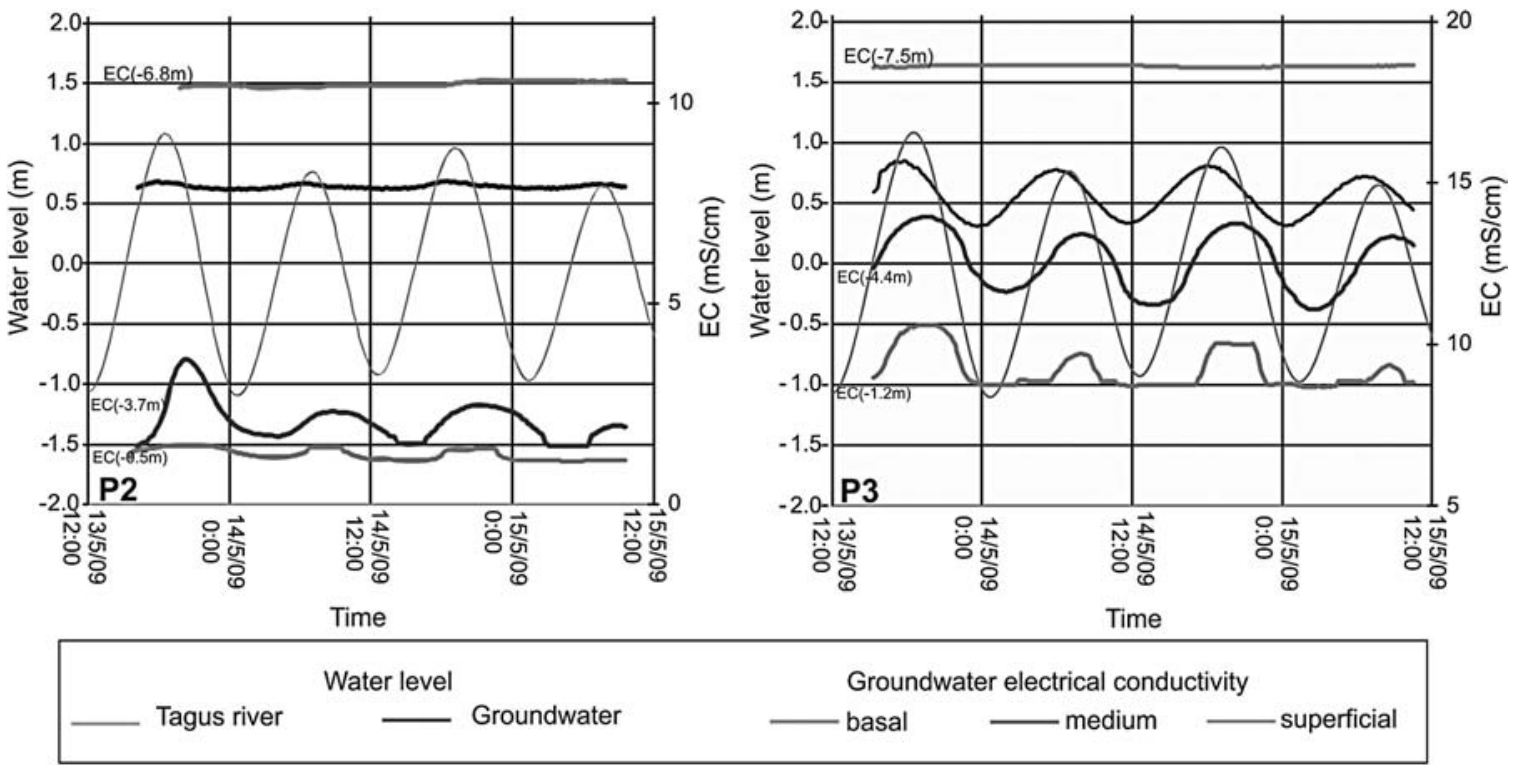

Figure 3 | Diagram of groundwater level and EC variations at different depths in Wells 2 and 3, and of the tide in the Tagus River depending on the time. (Full colour version available online.)

tide, whereas at syzygy increases of up to $0.75 \mathrm{~m}$ are recorded (Figure 4). The highest groundwater level peaks occur before the high tide peaks in the river. The EC of groundwater at the base of the aquifer $(-16.4 \mathrm{~m})$ does not show large variations, with an average value of $42 \mathrm{mS} / \mathrm{cm}$. This high value is only representative of the deepest sections of the aquifer, since the average EC records of groundwater are $4.2 \mathrm{mS} / \mathrm{cm}$ (at $-8.2 \mathrm{~m}$ ) and $3.0 \mathrm{mS} / \mathrm{cm}$ (at $-2.5 \mathrm{~m}$ ). At the base of the aquifer, no changes in the $\mathrm{EC}$ of groundwater depending on the tide are recorded, whereas at $-8.2 \mathrm{~m}$ and at $-2.5 \mathrm{~m}$ there is a tendency for $\mathrm{EC}$ to increase at low tide and when the high tide at the river is higher than the water table (Figure 5). The EC data at these depths show a similar behaviour, with larger variations in the shallower sections.

\section{Sector 3}

This sector is located in the vicinity of the apex of the alluvial cone, and comprises a section close to the Alcântara Channel, which is the main stormwater channel (Figure 1). The alluvial aquifer is composed of sand with limited clay intercalations that on the whole have a thickness of $7.6 \mathrm{~m}$ at Well 11 and $20 \mathrm{~m}$ at Well S1. The stormwater channel is permeable, so there is a direct connection between the aquifer and the water in the channel. In turn, the channel discharges into the river, which is why it constitutes a preferential pathway for the tidal flow from the river at high tide.

Well S1 is located $700 \mathrm{~m}$ from the riverbank and $2 \mathrm{~m}$ from the stormwater channel. The level records (Figure 6) show that at low tide the level remains at a stable value close to $0 \mathrm{~m}$. At high tide, the water table begins to rise, until it reaches a position similar to the one of the river, with maximum water table peaks occurring before the high tide peaks of the river. Another characteristic that should be noted is the fact that at quadrature the maximum water table peaks tend to exceed the ones of the high tide at the river, whereas at syzygy the high tide peaks slightly exceed the ones of the water table (Figure 6).

The EC values of groundwater obtained from three levels of the aquifer suggest the presence of brackish water with an average EC of $11 \mathrm{mS} / \mathrm{cm}$ at the base of the aquifer $(-15.4 \mathrm{~m})$, while in the middle and shallow sections $(-8.1$ and $-0.9 \mathrm{~m})$ the water has low salinity and an average EC close to $1.30 \mathrm{mS} / \mathrm{cm}$ (Figure 7). Even though there is salinity stratification, the EC of groundwater does not show significant variations depending on the tide. In the basal part of the aquifer, a decrease in salinity at high tide can be observed, with a maximum range of $0.5 \mathrm{mS} / \mathrm{cm}$ (Figure 7).

Well 11 is located at the same distance from the coastline as Well S1, but at approximately $50 \mathrm{~m}$ from the 

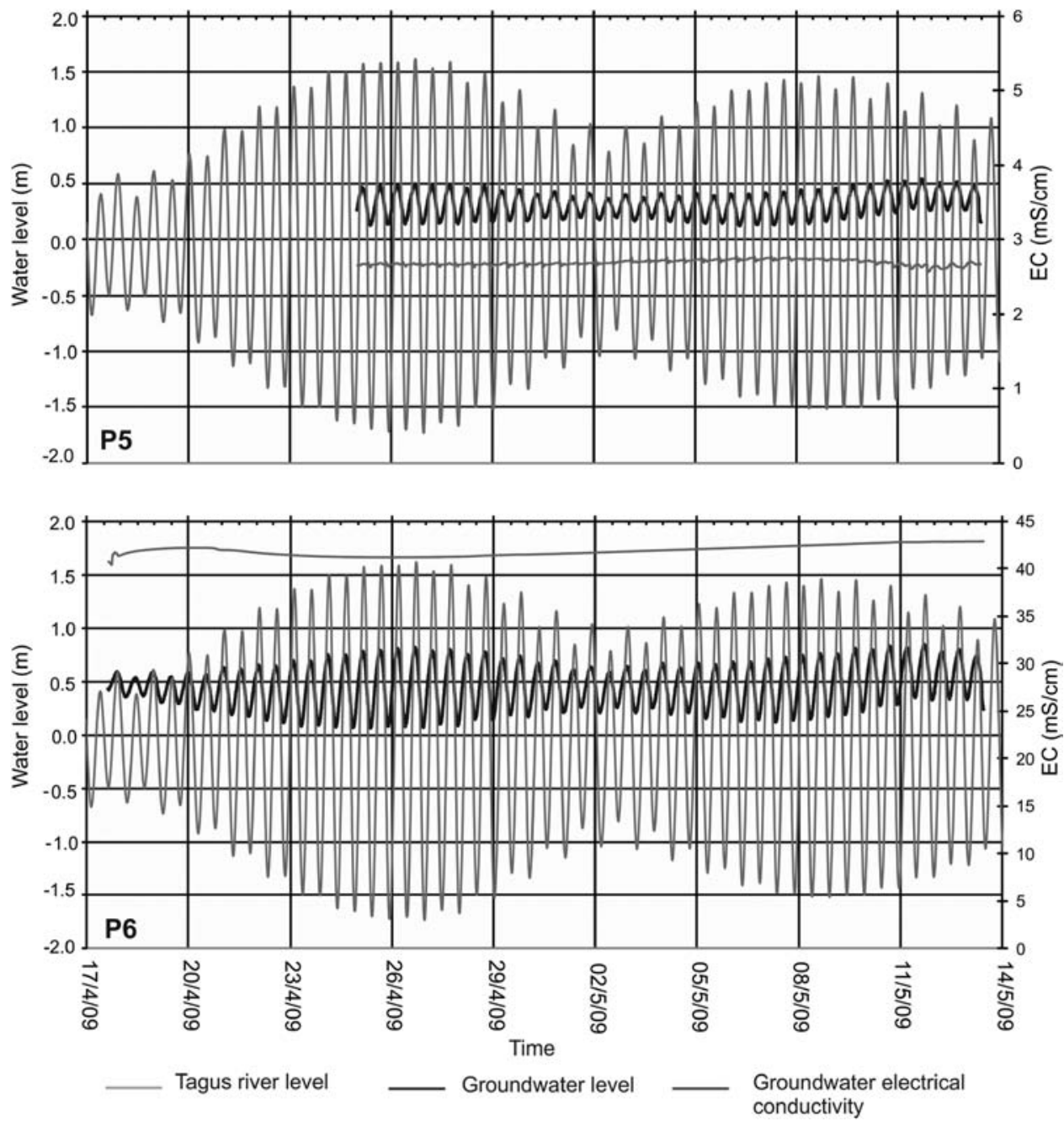

Figure 4 | Diagram of groundwater level and EC variations in Wells 5 and 6, and of the tide in the Tagus River depending on the time. (Full colour version available online.)

stormwater channel. At low tide, the water table is close to $0.50 \mathrm{~m}$, and it increases as the level of the river increases at high tide. As in Well S1, at quadrature the maximum peaks of the water table tend to exceed those of the river at low tide, whereas, at syzygy, the peak levels in the river at high tide slightly exceed those in the water table (Figure 6). The groundwater EC has an average value of $1.20 \mathrm{mS} / \mathrm{cm}$, with a slight decrease at high tide (Figure 7).

\section{Area of tidal influence and salt wedge}

The groundwater levels and EC depending on the tide in the river suggest spatial variations in the dynamics and salinity of the aquifer, with three sectors showing distinctive behaviours.

In Sector 1, the propagation of the tidal wave in the aquifer reaches at least $150 \mathrm{~m}$ from the coastline, generating variations in the water table, whose amplitude decreases as the distance from the coastline increases (Figure 8). The salinity stratification and the increase in EC of groundwater at high tide, together with an increase in the salinity concentrations towards the coast, are the characteristics that indicate the propagation of the tidal wave in the coastal aquifer. However, the increase in the water table as regards the groundwater-surface water interaction is associated with two processes. At the onset of the high tide, the level increase in the Tagus River prevents the groundwater 

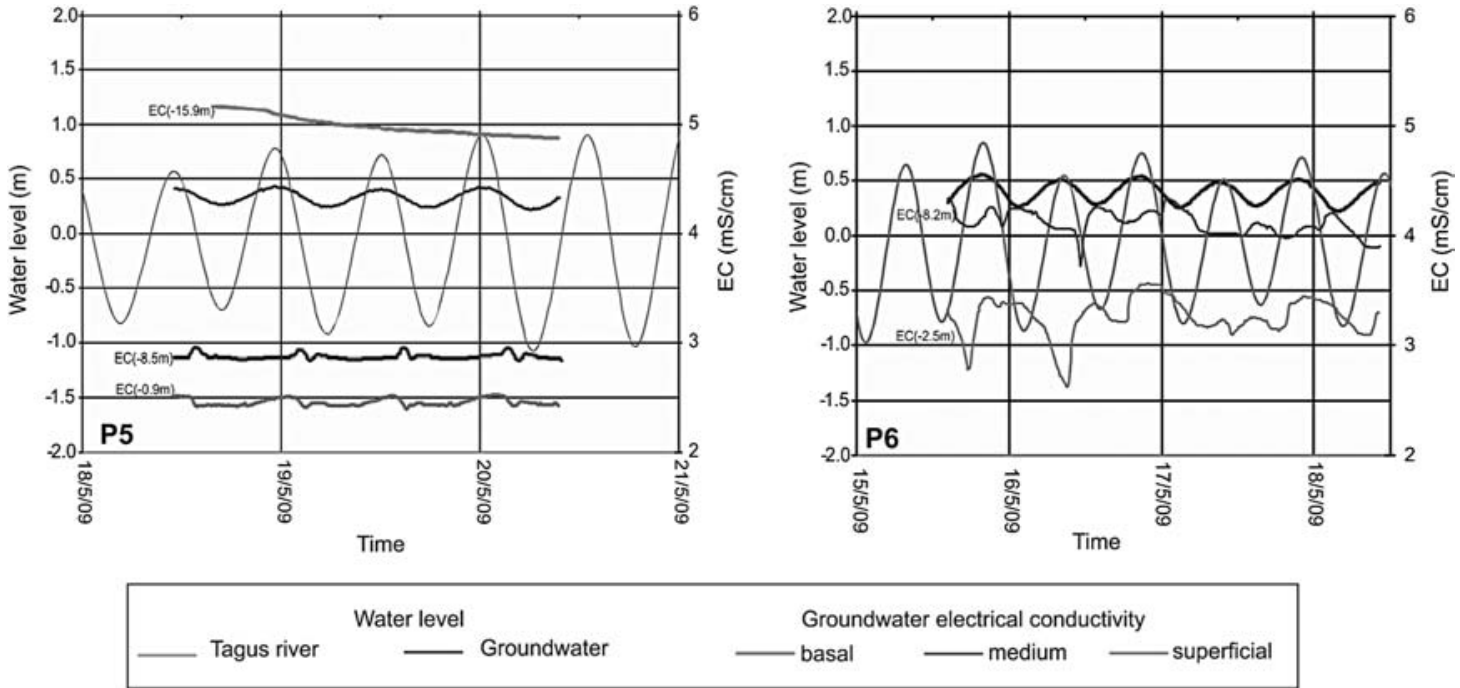

Figure 5 | Diagram of groundwater level and EC variations at different depths in Wells 5 and 6 , and of the tide in the Tagus River depending on the time. (Full colour version available online.)
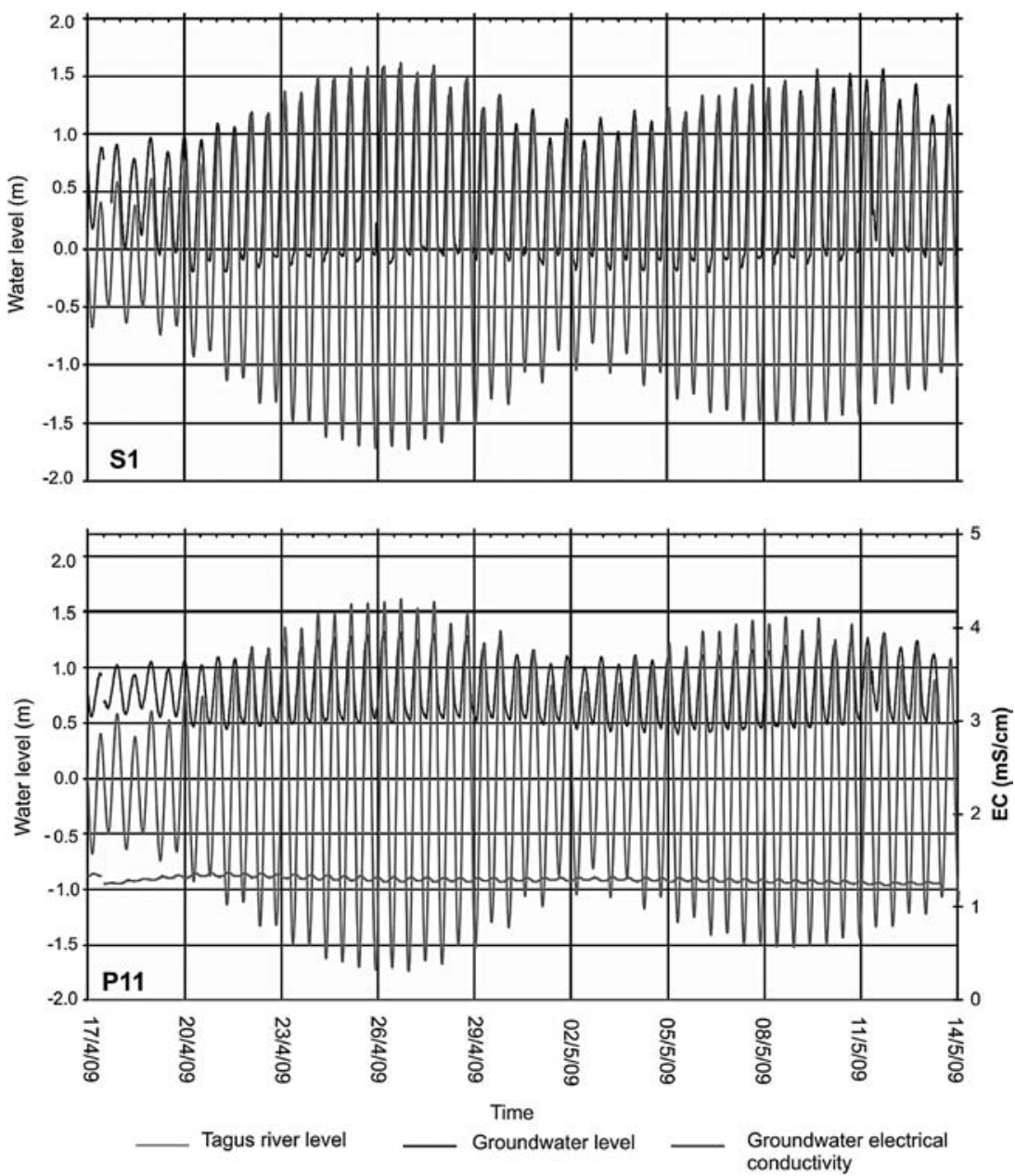

Figure 6 | Diagram of groundwater level and EC variations in Wells S1 and 11, and of the tide in the Tagus River depending on the time. (Full colour version available online.) 

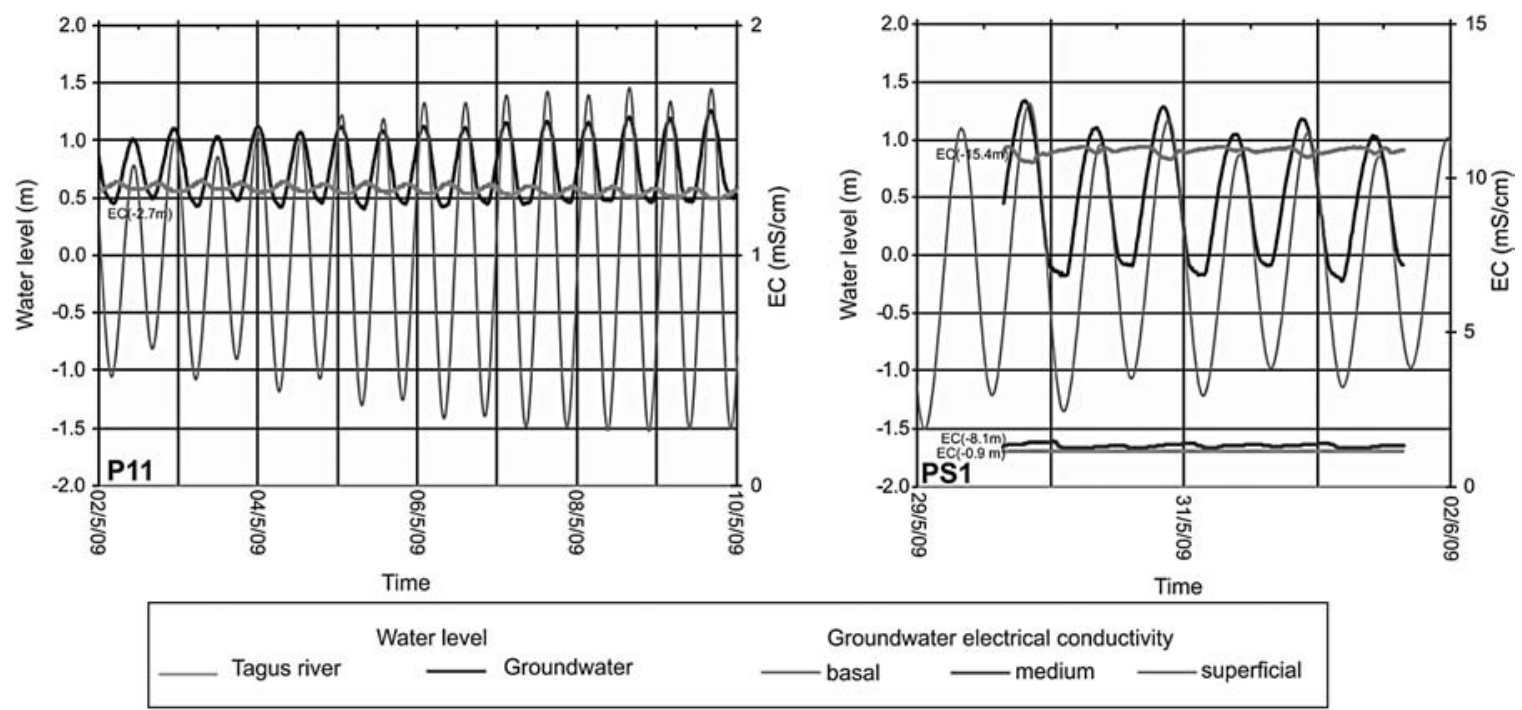

Figure 7 | Diagram of groundwater level and EC variations at different depths in Wells S1 and 11, and of the tide in the Tagus River depending on the time. (Full colour version available online.)

discharge towards the river, which causes groundwater to accumulate and the water table to rise, without increasing the salinity. Subsequently, when the high tide in the river rises over the level of the water table, the surface water flows from the river to the aquifer, causing the water table to continue rising and triggering an increase in the EC of groundwater. These two processes are evident in the relationship that exists between the high tide peaks in the river, and the level and EC peaks in the aquifer, with the water level peaks occurring before the tidal peak in the river and the EC peaks in groundwater being delayed with respect to the high tide in the river.

In Sector 2, the tide has an influence over the innermost sections of the aquifer with respect to Sector 1 . This is due to the fact that the docks of the Santo Amaro port is an area where the alluvial cone in which the aquifer occurs has been undermined and where the tide from the river may penetrate freely (Figure 8). Water table fluctuations are recorded up to $300 \mathrm{~m}$ from the riverbank, with the maximum water table level occurring before the high tide in the river in the dock area, and after the high tide in the river in the more distant areas. In the vicinity of the docks, the aquifer shows a marked salinization at the base (over $40 \mathrm{mS} / \mathrm{cm}$ ), but not on the surface and the more distant sectors in which the EC is less than $5 \mathrm{mS} / \mathrm{cm}$. In the zone near the docks, the EC of groundwater tends to decrease at high tide in the middle section of the aquifer, a tendency that is less noticeable on the surface. This characteristic, together with the occurrence of the maximum water table level before the high tide in the river, may be indicating that at the onset of the high tide there is an accumulation of freshwater in the aquifer, which cannot be discharged when the level in the river rises. In turn, the irregularity in the EC records in the superficial sections may be associated with the fact that the lateral cement walls of the docks cause an irregular propagation of the tidal wave towards the aquifer.

Sector 3 is most distant from the coastline; however, the largest oscillations of the water table in response to the tide are recorded there. Groundwater salinity is low, and the EC of groundwater in the middle and shallow sections are below $1.3 \mathrm{mS} / \mathrm{cm}$, with a slight decrease at high tide. This behaviour of the groundwater levels and EC is caused by the fact that the stormwater channel constitutes a preferential pathway for the tidal flow towards the interior of the alluvial fan. Upon the entrance of tidal water at high tide, the rainwater discharge is blocked and it tends to accumulate in the channel, causing a rise in the water level (Figure 8), which reaches a level similar to the one in the river during neap tides and exceeds the one in the river during spring tides. As the walls of the channel are permeable, the freshwater that accumulates in the channel enters the aquifer, causing a decrease in EC and a rise in 

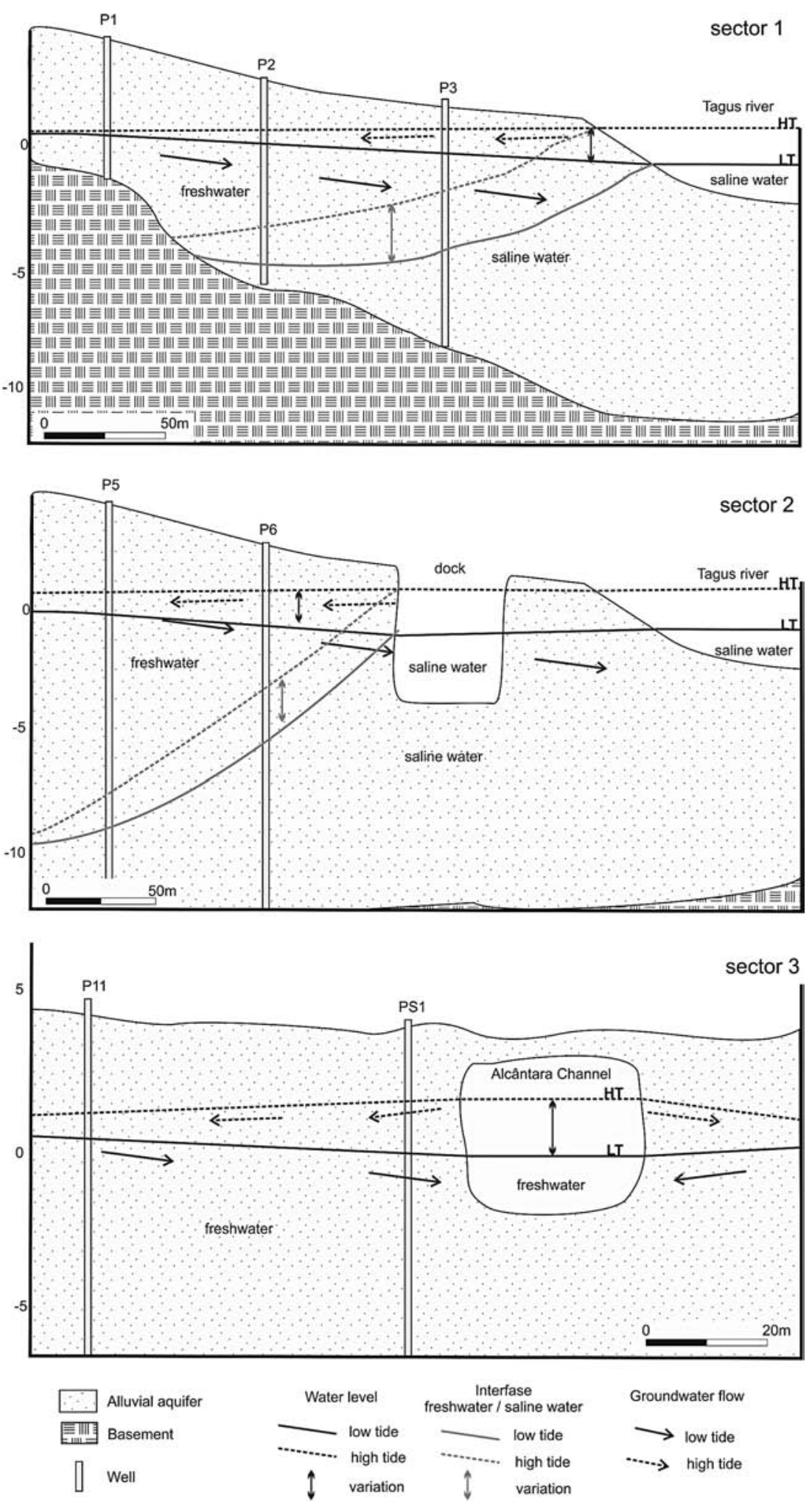

Figure 8 Diagram indicating the relationship between the Tagus River water and the aquifer at low tide (LT) and high tide (HT) for the three sectors studied. (Full colour version available online.) 
the water table, which reaches values similar to the ones in the channel and the river.

The distribution of the wells that show high EC values at depth and a significant level variation in relation to the tide allows the identification of the coastal area affected by saline intrusion, which reaches a surface of $0.38 \mathrm{~km}^{2}$ (Figure 9). The narrowest coastal strip affected by saline intrusion (150 m wide) is located to the west of the study area, in the sector with no docks. In the central and eastern sectors, the salinized strip includes the Santo Amaro and Alcântara docks, with the salinized area widening from the Tagus River bank up to a width of $350 \mathrm{~m}$. In the image shown in Figure 9, it can be observed that the salinized sector comprises urban areas that have foundations and underground constructions (parking garages) in contact with the salinized groundwater and in which significant tidal oscillations occur.

To the north, and in the vicinity of the Alcântara Channel, there is a non-salinized area but with strong tidal oscillations (Figure 9). This $0.06 \mathrm{~km}^{2}$ area also comprises an important number of constructions whose foundations are in direct contact with groundwater.

\section{DISCUSSION}

The study of groundwater behaviour in coastal areas requires undertaking fieldwork and detailed measurements in order to understand the spatial variations in hydrodynamics and salinity. The complexity that characterizes coastal aquifers, especially those associated with significant urban development, requires greater detail in the understanding of such variables. This is an indispensable basis for a correct simulation that would enable, by means of a mathematical model, the planning and design of underground engineering works.

In this regard, it should be taken into consideration that the urban development in large cities includes an increasing, intensive underground occupation due to the construction of different types of infrastructure that may be near or in contact with the water table. The stability of underground engineering works, such as parking garages, areas of commercial use, tunnels, urban buildings with deep foundations, underground transport constructions, etc., depends to a large extent on the characteristics of the substratum on which they lie, with the thickness of the

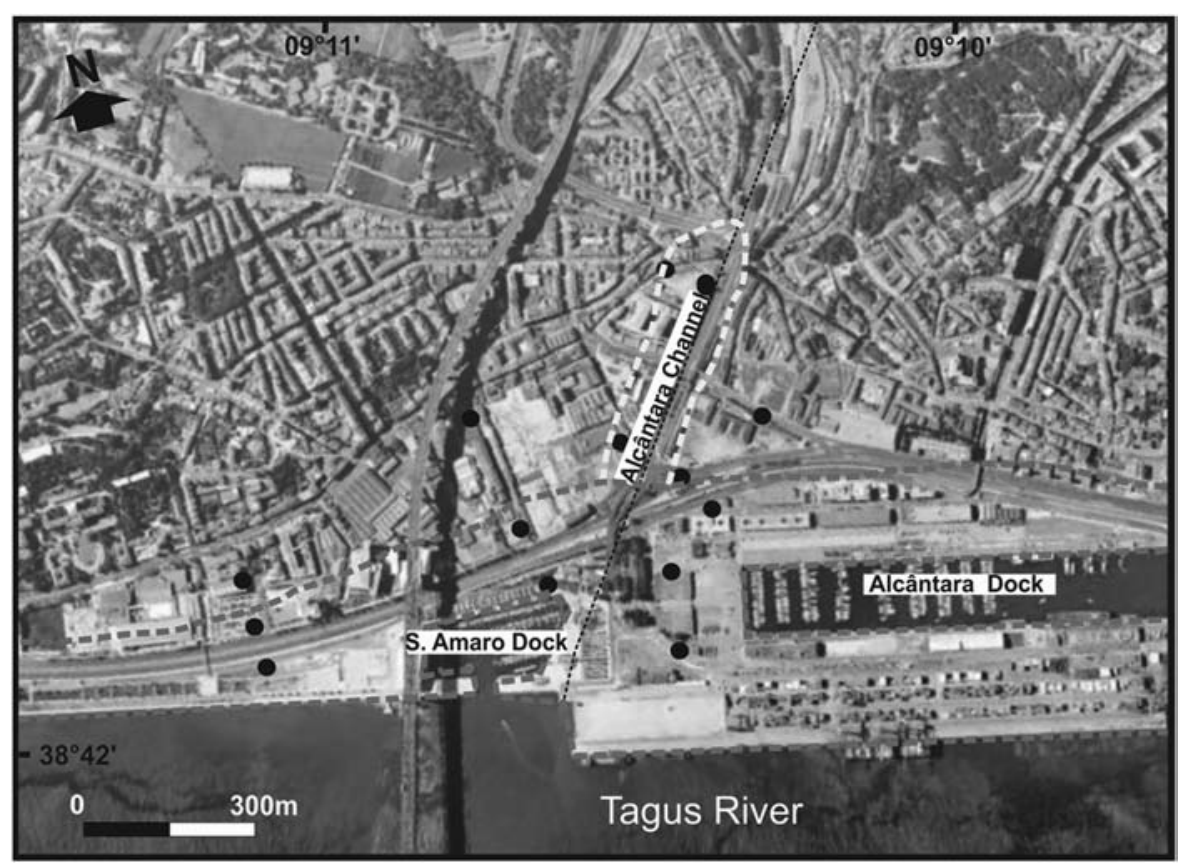

Figure 9 | Location of area of tidal influence and of the salt wedge. The dotted lines bordering the Tagus River, Alcântara Dock and stretching a few hundred metres inland indicates the area with saltwater intrusion. The dotted line surrounding the Alcântara Channel indicates the area of fresh water with strong tidal oscillation. (Full colour version available online.) 
non-saturated zone and groundwater salinity being parameters of importance to be considered in construction projects (Aitcin 2003).

The presence of such underground structures interacts with groundwater (Vazquez-Suñe et al. 2005). This interaction may occur in two ways. One is related to the effect that a structure with a different hydraulic conductivity causes when it modifies the natural groundwater flow. The other is associated with the effect that groundwater may have when it filters through such a structure (Carrera \& Vázquez Suñé 2008). In the latter case, the degree of influence depends on the variability in salinity and in the oscillations of the water levels, with a higher corrosion rate and chemical attack of the structures built underground in the coastal areas with marine influence (Wegen et al. 1993; Costa \& Appleton 1999; Aitcin 2003).

The hydrodynamic and salinity variability as a consequence of the tidal influence shows different effects in the alluvial cone on which the city of Lisbon is located. The large underground parking garages related to Sector 1 constitute impermeable obstacles that locally modify the natural groundwater flow. The shallow depth of the water table causes such structures to maintain constant interaction with the groundwater. The stratification and salinity variation of groundwater may affect the concrete structures, especially those of the parking garages located closer to the coastline.

The construction of docks in Sector 2 altered the natural hydrological behaviour, favouring tidal propagation and, consequently, causing larger oscillations of the water table and the penetration of the salt wedge into the innermost sections of the aquifer. These characteristics should be taken into consideration when construction works are undertaken in this sector, as well as in the construction projects for new docks, which may affect the existing constructions.

The existence of a permeable drainage channel discharging into the river constitutes a preferential pathway for the tide in sectors that are distant from the coastline (Sector 3). This modifies the natural water flow conditions, generating large variations in level in sections of the aquifer that are very distant from the coastline and where the water table oscillations as a consequence of the tide should be minimal. Even though in this sector the salinization of the groundwater is low, the periodical variation in the levels causes stress in constructions, with the possibility that the chemical attack of concrete by groundwater may be stronger than the one by seawater (Santhanam et al. 2006).

An understanding of the hydrodynamic and salinity characteristics of the environment may contribute to the planning of underground space occupation, such as the scale and location of underground structures, the selection of alternatives and a project for hydrogeological impact mitigation, as well as the selection of materials which would optimize the useful life of such structures in unsaturated/ saturated zone interface environments and in areas with salinity variability due to tidal influence. For instance, the data used in this work made it possible to generate a model of hydrological behaviour which was applied to the design of a future underground tunnel connecting two lines of suburban trains in Lisbon (Mancuso et al. 2008, 2009; Mancuso \& Pina 20II). Besides, both the data and the model are available from the Lisbon City Council to be used by the engineers responsible for issuing building permits and providing counsel for the construction of new buildings, underground parking garages, etc.

\section{CONCLUSIONS}

The groundwater level and EC data collected at different depths made it possible to observe the variability of such parameters within the alluvial aquifer concerning its three spatial components. The tidal fluctuation in the river and the anthropogenic alterations of the environment determine the existence of different behaviours in the dynamics of the aquifer. There are sectors in which the tidal wave typically propagates towards the aquifer (Sector 1), affecting to a larger extent the sectors closer to the coast. On the other hand, it can be observed that the inner sectors of the alluvial fan that are close to the docks (Sector 2) may have a larger dynamic and salinity variability than the coastal sectors, due to the fact that the excavations of the docks favour the tidal propagation towards the aquifer. In both cases (Sectors 1 and 2), the high tides are associated with rises in the water tables and salinity of groundwater. Similarly, in the sectors with a stronger tidal influence, the aquifer tends to have a marked salinity stratification, a characteristic which maximizes the salinity variability of the aquifer. 
Towards the apex of the alluvial fan, and associated with the dynamics of the storm water channel (Sector 3), the aquifer shows larger periodical oscillations in the water table as a result of the tides. In this sector, it is not the case that the saline tidal flow enters the aquifer, but rather that the freshwater that cannot drain towards the river enters the aquifer at high tide, causing a slight decrease in salinity content. Salinity stratification tends to decrease along the entire water column at high tide; the most basal sections of the aquifer, however, contain brackish water.

Being aware of the dynamic and salinity variability of shallow aquifers in areas with significant urban development is essential to develop land use planning policies that would tend to minimize the impact on the water flows and maximize the durability of constructions in time.

\section{REFERENCES}

Aitcin, P. C. 2003 The durability characteristics of high performance concrete: a review. Cement Concrete Comp. 25 409-420.

Alcoforado, M. J., Andrade, H., Lopes, A. \& Vasconcelos, J. 2009 Application of climatic guidelines to urban planning: the example of Lisbon (Portugal). Landsc. Urban Plan. 90, 56-65.

Almeida, F. M. 1986 Carta Geológica do Concelho de Lisboa. Direcção-geral de Geologia de Minas. Serviço Geológico de Portugal. Gravado e Composta em Geocart. Serviço Cartográfico do Exército. Escala 1, 10000.

Antonellini, M., Mollema, P., Giambastiani, B., Bishop, K., Caruso, L., Minchio, A., Pellegrini, L., Sabia, M., Ulazzi, E. \& Gabbianelli, G. 2009 Salt water intrusion in the coastal aquifer of the southern Po Plain, Italy. Hydrogeol J. 16, 1541-1556.

Carol, E., Kruse, E. \& Mas Pla, J. 2009 Hydrochemical and isotopical evidence of ground water salinization processes on the coastal plain of Samborombón Bay, Argentina. J. Hydrol. 365, 335-345.

Carol, E., Dragani, W., Kruse, E. \& Pousa, J. 2012 Surface water and groundwater characteristics in the wetlands of the Ajó River (Argentina). Cont. Shelf Res. 49, 25-33, doi:10.1016/j. csr.2012.09.009.

Carrera, J. \& Vázquez Suñé, E. 2008 Sobre la interacción entre acuíferos y obras subterráneas. El agua y las infraestructuras en el medio subterráneo. AIH-GE, Barcelona, 21-38.

Costa, A. \& Appleton, J. 1999 Chloride penetration into concrete in marine environment - Part I: main parameters affecting chloride penetration. Mater. Struct. 32, 252-259.

Currell, M., Cendón, D. I. \& Cheng, X. 20I3 Analysis of environmental isotopes in groundwater to understand the response of a vulnerable coastal aquifer to pumping: Western Port Basin, south-eastern Australia. Hydrogeol. J. 21, 1413-1427.

França, S., Vinagre, C., Caçador, I. \& Cabral, H. N. 2005 Heavy metal concentrations in sediment, benthic invertebrates and fish in three salt marsh areas subjected to different pollution loads in the Tagus Estuary (Portugal). Mar. Pollut. Bull. 50, 998-1003.

Ghabayen, S., McKee, M. \& Kemblowski, M. 2006 Ionic and isotopic ratios for identification of salinity sources and missing data in the Gaza aquifer. J. Hydrol. 318, 360-373.

Giambastiani, B. M. S., Antonellini, M., Oude Essink, G. H. P. \& Stuurman, R. J. 2007 Saltwater intrusion and water management in the unconfined coastal aquifer of Ravenna (Italy): a numerical model. J. Hydrol. 340, 91-104.

Gjørv, O. E. \& Vennesland, Ø. 1979 Diffusion of chloride ions from seawater into concrete. Cement Concrete Res. 9, 229-238.

Jinjie, S. \& Wei, S. 20II Effect of sulfate ions on the corrosion behavior of steel in concrete using electrochemical methods. Adv. Mat. Res. 163-167, 3049-3054.

Jun, S., Bae, G. \& Lee, K. 2013 Factors causing dynamic variations in the saltwater-freshwater transition zone in a beach aquifer, Mangsang, South Korea. Hydrogeol. J. 21, 1355-1371.

Kim, K. Y., Seong, H., Kim, T., Park, K. H., Woo, N. C., Park, Y. S., Koh, G. W. \& Park, W. B. 2006 Tidal effects on variations of fresh-saltwater interface and groundwater flow in a multilayered coastal aquifer on a volcanic island (Jeju Island, Korea). J. Hydrol. 330, 525-542.

Mancuso, M. A. \& Pina, B. 20 Modelo matemático do escoamento subterrâneo no vale de Alcântara. 1. Relatório de Modelação da Fase 3: Actualização do modelo conceptual e Análise de sensibilidade. Proc. 0504/1/17219. Proc. Int. 0504/541/1293. Portugal. REFER. Relatório Técnico 407/ 2011 - NGEA. LNEC. p. 43.

Mancuso, M. A., Lobo Ferreira, J. P., Oliveira, M. M., Novo, M. E. \& Henriques, M. J. 2008 Modelo Matemático do Escoamento Subterrâneo no Vale de Alcântara. Relatório Sectorial da Fase 1: Águas Subterrâneas. Relatório Técnico 378/2008 NAS. LNEC. p. 59.

Mancuso, M. A., Novo, M. E. \& Lobo Ferreira, J. P. 2009 Modelo Matemático do Escoamento Subterrâneo no Vale de Alcântara. 1 Relatório Sectorial da Fase 2: Águas Subterrâneas. Relatório Técnico 229/2009 - NAS. LNEC. p. 47.

Park, S., Yun, S., Chae, G., Yoo, I., Shin, K., Heo, C. \& Lee, S. 2005 Regional hydrochemical study on salinization of coastal aquifers, western coastal area of South Korea. J. Hydrol. 313, 182-194.

Rosenthal, E., Zilberbrand, M. \& Livshitz, Y. 2007 The hydrochemical evolution of brackish groundwater in central and northern Sinai (Egypt) and in the western Negev (Israel). J. Hydrol. 337, 294-314.

Santhanam, M., Cohen, M. \& Olek, J. 2006 Differentiating seawater and groundwater sulfate attack in Portland cement mortars. Cement Concrete Res. 36, 2132-2137. 
Shapouri, M., Cancela da Fonseca, L., Iepure, S., Stigter, T., Ribeiro, L. \& Silva, A. 2015 The variation of stygofauna along a gradient of salinization in a coastal aquifer: the variation of stygofauna along a gradient of salinization in coastal aquifer.

Q2 Hydrol. Res., doi:10.2166/nh.2015.153 (in press).

Silva-Filho, E. V., Sobral Barcellos, R. G., Emblanch, C., Blavoux, B., Sella, S. M., Daniel, M., Simler, R. \& Wasserman, J. C. 2009 Groundwater chemical characterization of a Rio de Janeiro coastal aquifer, SE - Brazil. J. S. Am. Earth Sci. 27, 100-108.
Surinaidu, L. 2015 Role of hydrogeochemical process in increasing groundwater salinity in the central Godavari delta. Hydrol. Res. doi:10.2166/nh.2015.050 (in press).

Vazquez-Suñe, S., Sanchez-Vila, X. \& Carrera, J. 2005 Introductory review of specific factors influencing urban groundwater, an emerging branch of hydrogeology, with reference to Barcelona, Spain. Hydrogeol. J. 13, 522-533.

Wegen, G. V., Bijen, J. \& Selst, R. 1993 Behaviour of concrete affected by sea water under high pressure. Mater. Struct. 26, 549-556.

First received 15 October 2015; accepted in revised form 12 January 2016. Available online 19 February 2016 


\section{Author Queries}

Journal: Hydrology Research

Manuscript: HYDROLOGY-D-15-00203

Q1 Franca et al. (2005) has been changed to FrancSa et al. (2005) as per the reference list.

Q2 Please update volume and page number for Shapouri et al. (2015).

Q3 Please update volume and page number for Surinaidu (2015). 